\title{
How Has the U.S. Treated American Muslim Minorities?
}

\author{
Dr. John L. Esposito \\ Distinguished University Professor | Georgetown University \\ Symposium on The State of Muslim Minorities in Contemporary Democracies \\ Muqtedar Khan (Ed.) \\ International Institute of Islamic Thought | June 2021 \\ DOI: http://doi.org/10.47816/02.001.symposium3.jesposito
}

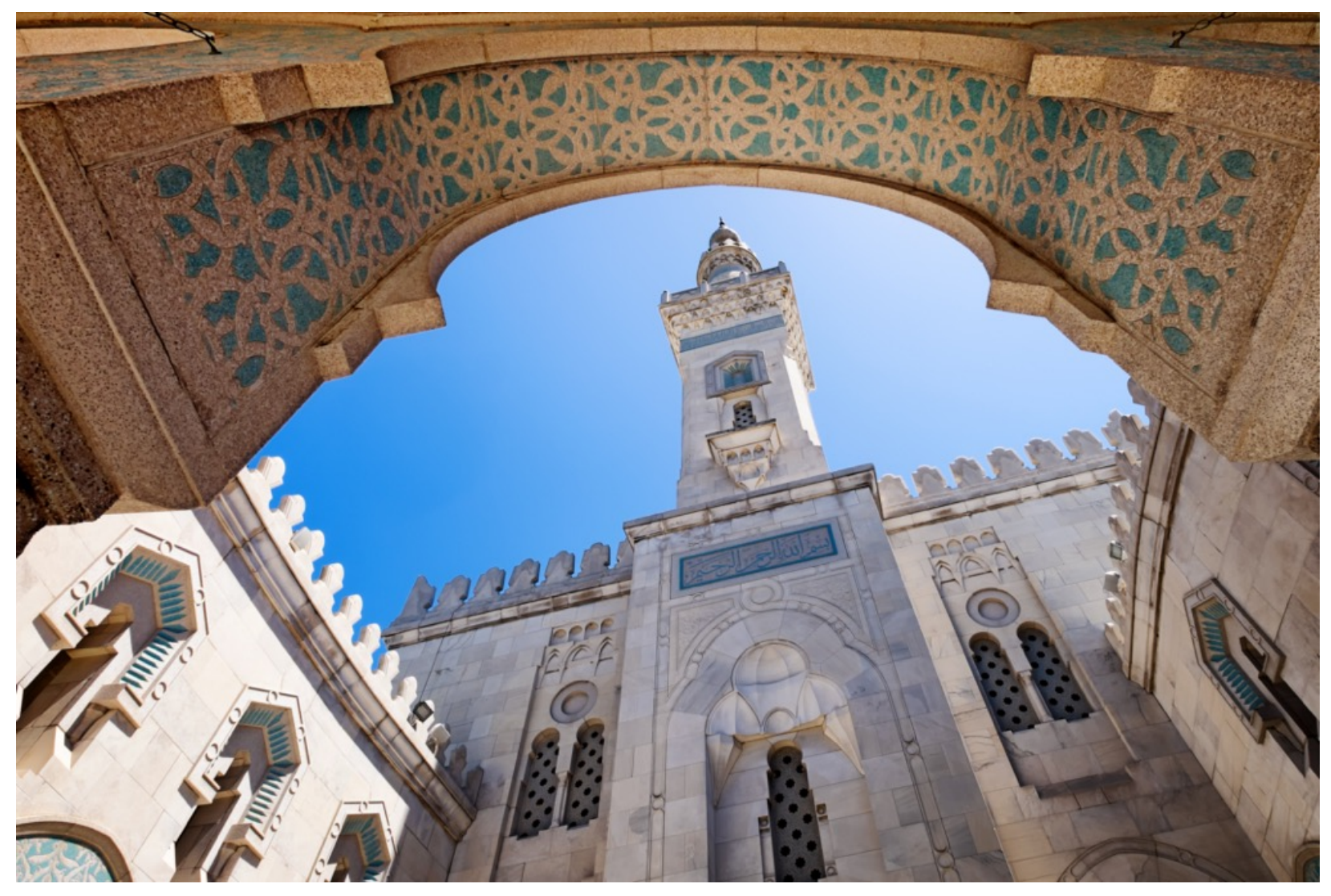

\section{Islamic Center of Washington DC}

America's religious landscape and its religious pluralism have been transformed dramatically since the last decades of the $20^{\text {th }}$ century. A Judeo-Christian and secular United States has now expanded its religious boundaries to include large populations of Muslims, Hindus, Buddhists, Sikhs, and others. 
In America, Islam has emerged as the third largest religion. Major Muslim communities stretch from Boston, New York City, and Washington, D.C., to Detroit, Chicago, and Minneapolis, to Houston, San Francisco, and Los Angeles. Many landscapes now include mosques and Islamic centers alongside churches, synagogues, Hindu and Buddhist temples, as well as Sikh Gurdwaras.

Although Arab Muslim and Christian immigrant laborers came to America in the late $19^{\text {th }}$ century, a major and significant increase in the Arab, Asian, and African Muslim population occurred in the mid-to-late $20^{\text {th }}$ century. Many American Muslims today are the children and grandchildren of immigrants who came in pursuit of political and religious freedom, economic prosperity, or education. Well-educated professionals, intellectuals, and students came from the Middle East, South and Southeast Asia, as well as Africa, often leaving a life under authoritarian regimes and failed economies to seek a better future. Muslim students were also sent by their governments to study in America with the expectation that they would return with their knowledge and skills to their home countries - some did; many did not. In addition to Muslims who more recently immigrated to the U.S., a significant and diverse minority (20\% of American Muslims), are predominantly African Americans, long-term citizens, descendants of slaves, and converts to Islam.

In America, knowledge of Islam and the Muslim world was very limited before the newsbreaking story of the Iranian Revolution. Coverage of Islam and Muslims in the media or in most universities and colleges, as well as in secondary education, was negligible. Scholars of Islam, Muslim history, and politics were few and far between. The American Academy of Religion (AAR), the oldest and largest professional organization devoted to the study of religion, had little to no inclusion of Islam. The AAR did not have a task force on Islam until the mid-1970s; Islam 
was finally officially recognized as a permanent program unit in 1986. Although Islam was the second largest world religion, coverage of Islam, Muslim history and culture were totally absent in the training of foreign service officers or the training of diplomats nor was it a consideration in Western foreign policy. In the U.S., media coverage of Islam and Muslims was sparse.

Nevertheless, during the last half of the $20^{\text {th }}$ century, Muslims who immigrated were making new lives in a new world and were becoming part of mainstream America. They were integrating themselves economically, socially, and increasingly politically into American society.

The Muslim population in America is young. Fifty-nine percent are between the ages of 18 and 39, compared to just 39 percent of those in the general public. Many young Muslim males and females emphasize education. Thirty-one percent of Muslims are full-time students, a more than three-fold difference above the U.S. general population. A quarter of U.S.

Muslims are enrolled in college compared to just 13 percent of the general public and 27 percent of the native born. ${ }^{1}$ Muslim women $(73 \%)$ were more likely than Muslim men (57\%) to pursue higher education beyond high school. ${ }^{2}$

Muslims' employment profiles span the socio-economic spectrum. They work as physicians, lawyers, engineers, educators, corporate executives, small business owners, bluecollar workers, and laborers. A Pew 2011 survey reported that Muslim Americans were about as likely to live in a household with an income of $\$ 100,000$ a year or above as the general public. ${ }^{3}$ Gallup found that $70 \%$ had a job, the highest of any religious group surveyed and above the $64 \%$ reported for the general population. A full $30 \%$ of those employed were in the professions, $4 \%$ points ahead of the U.S. general population. ${ }^{4}$ Muslim self-employment (24\%) is the highest among any religious group and seven percentage points above the general population. ${ }^{5}$ 


\section{The War against Global Terrorism and Muslim Civil Liberties}

The American Muslim community, like many immigrant ethnic and religious communities, has experienced multiple political, economic, and cultural challenges, especially due to fallout from world events. Americans went from knowing little about Islam and Muslims to witnessing the Iranian Revolution of 1978-79 led by the Ayatollah Khomeini: Full media coverage highlighted American embassy personnel taken hostage in Teheran while crowds that resented America's return of their Iranian Shah to power after he had been deposed vehemently shouted "Death to America" on TV screens.

International and domestic events that followed into the $21^{\text {st }}$ century - the attacks of alQaeda, 9/11, and ISIS - continued to fill Americans' knowledge gap with negative coverage of Islam and Muslims. The rise of white nationalism and supremacism in America intensified fears of Islam and brush-stroked the entire Muslim community with terrorist images and distortions of Islam as the new emerging threat to America and Western Civilization. Amidst such conditions many Muslims have experienced discrimination and threats to their safety, security, and civil liberties. What are some of the voices and events that have had serious repercussions for the American Muslim community?

In the post-Cold War period, with the fall of the Soviet Union, many government officials, politicians, media pundits, scholars, and some religious leaders began to see Islam and Islamic fundamentalism as the next impending global force. In the early 1990s, prominent academics like Bernard Lewis in "The Roots of Muslim Rage" and Samuel Huntington in The Clash of Civilizations warned of a clash between Islam and the West. Islam was cast as a historical, political, civilizational, and demographic menace. 
A key example of growing suspicion of Muslims in America occurred in 1996 with the bombing of the FBI headquarters in Oklahoma City that was initially falsely attributed to Arab Muslims. As a result, throughout the United States, Arab and Muslim Americans suffered hate crimes - from bomb threats to verbal denunciations. In fact, ultimately Timothy McVeigh, a former member of the U.S. military and a right-wing extremist, was indicted, tried, and executed for the bombing. Still, fear of Muslims did not dissipate. Responding to what was branded as a new domestic "threat," Congress passed the Anti-Terrorism and Effective Death Penalty Act (the so-called "secret evidence" act).

Although this new law had been a direct response to the tragic Oklahoma City bombing perpetrated by a white Christian American, the law came to specifically target non-citizens. The practice of using secret evidence to detain individuals, a gross violation of the basic constitutional right to due process, would have normally been alarming to most Americans. However, the issue was publicly framed in the context of protecting national security and defending the country against potential terrorists. Within months of the law's passage, immigration authorities arrested a number of Muslims across the country using "secret evidence" that only an immigration judge could see. The accused men were imprisoned indefinitely, without being charged with any crime or given an opportunity to defend themselves in court.

In 2001, 9/11 brought new major obstacles and challenges for American Muslims. The impact of the terrorist attacks in New York (the World Trade Center) and in Washington, D.C. (the Pentagon), together with subsequent attacks in London, Spain, and Bali, underscored the global threat of Osama Bin Laden and al-Qaeda, raising new questions about the religion of Islam and the loyalty of all American Muslims. While President George W. Bush called upon Americans to distinguish between the religion of Islam, a religion of peace, and al-Qaeda 
terrorists, the many voices of politicians, political commentators, media pundits, and religious leaders conflated mainstream Islam with religious extremism and terrorism. Fear and distrust inflated negative attitudes and behaviors towards mainstream Islam and Muslims (Islamophobia), and led to increased anti-Muslim hate speech, hate crimes, and a serious erosion of human rights.

The Bush administration subjected 80,000 Arab and Muslim immigrants to fingerprinting and registration, sought out 8,000 Arab and Muslim men for FBI interviews, and imprisoned over 5,000 foreign nationals in antiterrorism preventive detention initiatives. As part of this program, the government adopted an aggressive strategy of arrest and prosecution, holding people on minor charges - in fact, pretexts such as immigration violations, credit card fraud, or false statements, or, when it had no charges at all, as "material witnesses." 6

The manipulation of domestic anti-terrorism legislation, the 1996 Antiterrorism and Effective Death Penalty Act, established a new "secret evidence" court, charged with hearing cases in which the government deported aliens accused of engaging in terrorist activity, based on secret evidence in the form of classified information. The Patriot Act (2001) resulted in extrajudicial procedures and the erosion of civil liberties too.

The political climate also led to the 2002 creation of the U.S. military prison at the Guantánamo Bay Naval Base. It was located on land leased from Cuba to house suspected Muslim terrorists who were captured in the U.S.-led global "War on Terror." This location in Cuba enabled the U.S. to argue the base was not on U.S. soil. Prison detainees were designated as "enemy combatants" who could then be denied U.S. legal protections. ${ }^{7}$ They were detained 
without charges, denied access to lawyers and to bail, with evidence being withheld from them and their lawyers. Trials before military tribunals were not subject to judicial review.

Since its inception, 780 Muslim men and boys have been detained at this prison and 731 have been released without any charge. In total, over $98 \%$ of the detainees were not charged with any crime related to the 9/11 attacks. As David Cole concluded in Less Safe, Less Free, a study of the Bush administration's anti-terrorism policies: "In the name of preventing terrorism, the administration has locked up thousands of individuals without trial - within the United States and abroad - the vast majority of whom have never even been accused, much less convicted, of any terrorist act. ${ }^{8}$,

Major polls confirmed a changing climate in American society regarding the image of Islam and Muslims. When asked what respondents most admired about Muslim societies, "Nothing" was the most frequent response to a December 2005 Gallup Poll of American households. The second most frequent response was, "I don't know." Combined, these two responses represented the majority (57 percent) of Americans surveyed. ${ }^{9}$

In 2010, the building of an Islamic cultural center (Park 51), nicknamed by opponents as the so-called Ground Zero Mosque, but in fact located two blocks from Ground Zero in New York City, became a widely publicized controversy. The project, which was approved by all relevant government and local agencies, sparked not only intense opposition from some families of 9/11 victims but also mass protests at the site. Politicians, right wing media, bloggers, political pundits, and prominent Islamophobic writers and activists contributed to a situation that spiraled out of control.

Across the U.S., protesters, taking their cue from those at mass protests at the Park 51 site, charged that mosques were "monuments to terrorism." There was an increase in opposition 
to the building of mosques, accusations that mosques were a source of terrorism, as well as vandalism. Fear of "creeping Shari'ah" in America also emerged and spread like a tsunami after this incident. Since 2010, protestors have rallied across the U.S. and more than 216 bills to ban Shari'ah law have been introduced in 43 state legislatures. Arkansas, Florida, Kansas, Louisiana, North Carolina and Tennessee enacted legislation.

The issue affected 2008, 2012, and 2016 presidential as well as congressional elections. Republican candidates like Herman Cain (2012) and Ben Carson (2016) believed a Muslim should not be president unless they denounced their faith. In 2016, Republican candidates Newt Gingrich, Rick Santorum, and Donald Trump, among others, warned that Muslims wanted to implement Shari'ah.

\section{Media Coverage}

Mass and social media that focus on explosive, headline events, made Islamophobia a global constant with a significant impact on attitudes and behaviors towards Muslims in America. Media Tenor, a news organization that monitors international media, reported that after more than a decade of steady escalation, 2015 had witnessed the all-time highest level of negative coverage of Islam and Muslims: Over $80 \%$ of TV media news on Islam was negative. In the U.S., U.K., and Germany, nine out of 10 programs were negative. The majority of news coverage focused on ISIS and other 'Islamist' terrorist networks. Even reporting of mainstream Muslims (more than $50 \%$ of reports) tended to be negative. ${ }^{10}$

\section{Social Media}


The explosion of social media websites in recent decades included the emergence of an Organized Islamophobia Network (OIN) and anti-Muslim engineered campaigns. The Network includes a cottage industry of pundits, bloggers, authors, lobbyists, and elected officials, ideological, agenda-driven anti-Muslim polemicists, and their funders. The Center for American Progress Report, Fear, Inc., (August 2011) documented (based on IRS returns) that $\$ 42.6$ million flowed from seven foundations over 10 years to support Islamophobic authors and websites. ${ }^{11}$ In 2016, CAIR (Council on American-Islamic Relations) and the Center for Race and Gender at UC Berkeley issued a broader report, "Confronting Fear Report," detailing that, between 2008-2013, 33 Islamophobic groups had access to $\$ 205,838,077$ to support their efforts. ${ }^{12}$

\section{American Elections}

American political elections in 2008, 2012, and 2016 have served as another major driver for negative judgments toward Muslims and religion of Islam. Although Barack Obama was a self- proclaimed Christian, his Muslim name (from his non-practicing African Muslim father) and the fact that he and his American mother lived in Indonesia for a time, fed intense speculation and accusations espoused by Donald Trump and others that Obama was born in Indonesia and was a Muslim. The climate in America was reflected in the 2015 report of the Public Religion Research Institute: "no religious, social, or racial and ethnic group [was] perceived as facing greater discrimination in the U.S. than Muslims."13

In 2016, the politicization and racialization of Islam and Muslims played a central role in Donald Trump's campaign for president. Trump used rhetoric aimed at demonizing Muslims, immigrants, and refugees, stating throughout the campaign that he would "strongly consider" shutting down mosques. After the San Bernardino, California, attack in December 2015, Trump 
issued a "statement on preventing Muslim immigration," calling for a total and complete shutdown of Muslims entering the United States. Following the statement, anti-Muslim attacks in America occurred almost daily, and often multiple times a day during the month. Trump advocated a temporary freeze on all foreign Muslim immigration, as well as the monitoring or even the forced closure of American mosques. When on March 9, 2016, CNN's Anderson Cooper asked Trump if he thought "Islam is at war with the West," Trump responded, "I think Islam hates us... There's tremendous hatred there... We have to get to the bottom of it. There is an unbelievable hatred of us."

Now, "Islam," not simply Muslim terrorists, was the enemy. This common theme in the Trump campaign diverged from presidents George W. Bush's and Barack Obama's approaches to terrorism as they had attempted to differentiate between the faith of 1.6 billion people and the actions of dangerous and deadly religious extremists and terrorists.

After his election, the Trump administration, in both its rhetoric and policies, undermined the health of U.S. democracy: threatening domestic political rights and civil liberties for Muslims and other Americans. One week after he was inaugurated, to follow up on a campaign promise to ban all foreign Muslims from the US, Trump instituted he Muslim Ban, a Presidential Executive Order, subtitled "Protecting the Nation from Foreign Terrorist Entry into the United States" which restricted travel to the United States from a group of Muslim-majority countries.

While Trump administration policies reflected and reinforced negative rhetoric and attitudes towards Islam and Muslims, they also triggered an outpouring of support and solidarity. The response to the Muslim Ban, which affected immigrants and those who wished to come to America, saw protests in the U.S. and internationally. The day the executive order was signed by Donald Trump, more than two thousand people rushed to protest at John F. Kennedy 
International Airport in Queens, New York City. They included lawyers prepared to provide free advice, members of Black Lives Matter and other social movements, as well as citizens in general. Protests also occurred at other airports in the U.S. and internationally. ${ }^{14}$

\section{The Future of Islam and Muslims in America}

How are Muslims faring amidst continued challenges to their religion and identity in America? A Pew Report in 2017, "U.S. Muslims Concerned about Their Place in Society, but Continue to Believe in the American Dream," noted that half of American Muslims believed that it had become more difficult to be Muslim in the U.S. Forty-eight percent stated they had experienced at least one incident of discrimination in the past 12 months. However, paralleling such reports of discrimination, a large - and growing - share (49\%) of American Muslims said someone had expressed support for them because of their religion in the past year. In addition, $55 \%$ thought Americans in general are friendly toward U.S. Muslims, compared with just 14\% who say they are unfriendly ${ }^{15}$.

American Muslims are more likely than Muslims in many other largely Muslim-majority nations to have many non-Muslim friends. Only about a third (36\%) of U.S. Muslims say all or most of their close friends are also Muslims, compared with a global median of $95 \%$ in the 39 countries Pew surveyed.

A majority (62\%) thought their fellow Americans did not see Islam as part of mainstream U.S. society. This is especially relevant because roughly two-thirds of U.S. Muslims (65\%) said religion is very important in their lives. Fifty-nine percent reported praying at least daily and $43 \%$ said they attend religious services at least weekly. 
Thus, despite concerns about Islamophobia and its impact on them, American Muslims overwhelmingly said they were proud to be Americans, believed that hard work generally brings success in this country, and were satisfied with their own lives. Most were happier than the broader U.S. population with conditions in American society. ${ }^{16}$

For many years, polls have documented Muslims making significant contributions to their broader community. One-third of Muslims report working on community issues and donate to local charities. Muslim physicians operate free medical clinics and many Muslims provide monetary and personal support to natural disaster relief.

Muslims have also promoted religious pluralism and tolerance. Ninety percent have said Muslims should participate in interfaith activities and $85 \%$ said the influence of religion and moral values in American public life should increase with Muslims strongly emphasizing shared values with believing Christians and Jews and that they worship the same God as Christians and Jews do.

Muslim involvement in the political life of the United States has grown significantly over the years. Muslims have participated in presidential and local campaigns, supporting nonMuslim as well as Muslim candidates. Muslim candidates have increased in national as well as local elections. Keith Ellison, now the Attorney General in Minnesota, was the first Muslim elected to Congress in 2006. Currently, there are three Muslims in Congress: Andre Carson (2008) from Indiana, Ilhan Omar (2019) from Minneapolis, and Rashida Tlaib (2019) from Dearborn.

Despite a concern about the impact and dangers of Islamophobia and anti-Muslim legislation and policies, a majority of Muslims are integrated into American society and remain optimistic about their future. Polling by Gallup, Pew, and ISPU has tracked the integration of 
Muslims in America, reporting that American Muslims can be described as "largely middle class and mainstream." Muslims are part of the fabric of American society and are learning to assert their citizenship and fundamental rights as America's constitutional heritage encourages and requires ${ }^{17}$.

\section{Author Bio}

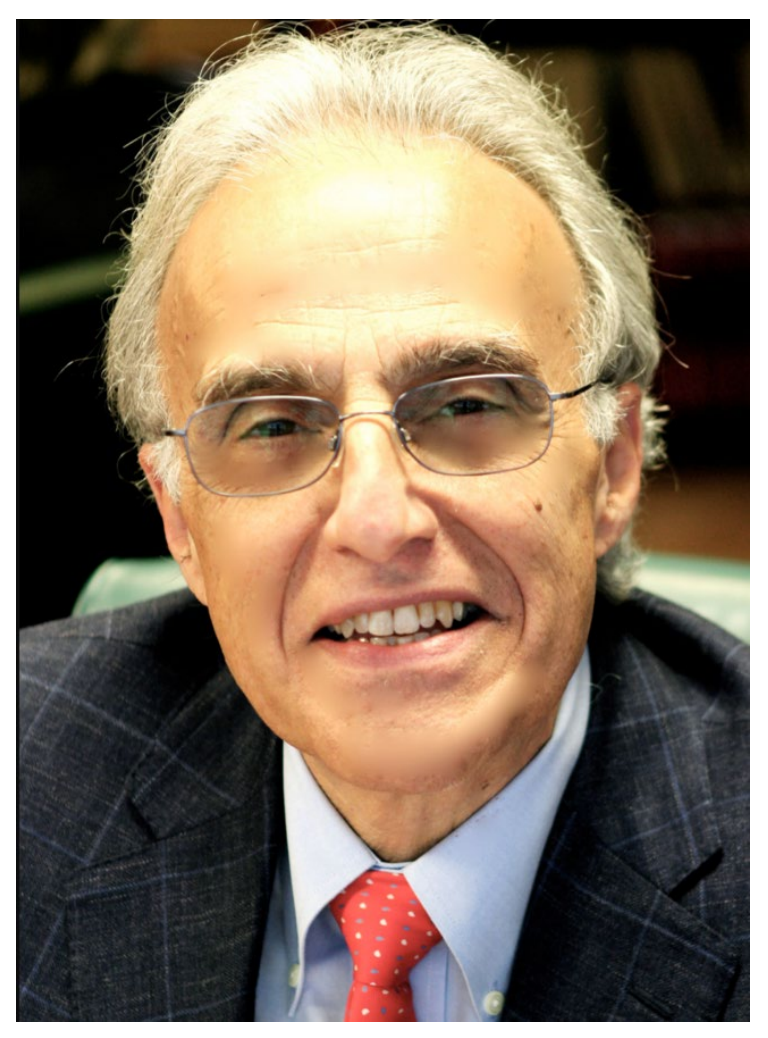

John L. Esposito is University Professor, Professor of Religion and International Affairs, and Professor of Islamic Studies at Georgetown University. John L. Esposito is Founding Director of the Alwaleed Center for Muslim-Christian Understanding and The Bridge Initiative: Protecting Pluralism - Ending Islamophobia in the Walsh School of Foreign Service. Esposito is also S. Rajaratnam Professor of Strategic Studies for 2019, Rajaratnam School of International Studies, Singapore. Previously, he was Loyola Professor of Middle East Studies, College of the Holy Cross. Past President of the American Academy of Religion and Middle East Studies Association of North America, Esposito has been a member of the World Economic Forum's Council of 100 Leaders and the E. C. European Network of Experts on De- 
Radicalization, a senior scientist for The Gallup Center for Muslim Studies, and an ambassador for the UN Alliance of Civilizations. He has served as a consultant to the U.S. Department of State and other agencies, European and Asian governments, corporations, universities, and media worldwide.

Esposito's more than 55 books include: Shariah: What Everyone Needs to Know (with Natana Delong-Bas; Oxford, 2018), Islam and Democracy after the Arab Spring (with J. Voll \& Tamara Sonn; Oxford, 2015), Religion and Violence (Mdpi AG, 2016), Who Speaks for Islam? What a Billion Muslims Really Think (with Dalia Mogahed; Gallup, 2008), What Everyone Needs to Know About Islam (Oxford, 2011), The Future of Islam (Oxford, 2013), Islamophobia: The Challenge of Pluralism in the 21st Century (Oxford, 2011), Unholy War: Terror in the Name of Islam (Oxford, 2003), The Islamic Threat: Myth or Reality? (Oxford, 1999), Islam and Politics, Makers of Contemporary Islam and Islam and Democracy (with John O. Voll; Oxford, 2001 -1996).

${ }^{1}$ Cato, "Muslim Assimilation Demographics in Education and Income" https://www.cato.org/blog/muslim-assimilation-demographic-educationincome-opinionsviolence\#: :text=A\%20quarter\%20of\%20U.S.\%20Muslims,above\%20the\%20U. S.\%20general\%20population.

${ }^{2}$ ISPU, "American Muslim Poll Findings, 2017" https://www.ispu.org/americanmuslim-poll-2017-key-findings

${ }^{3}$ Pew, "Muslim Americans Show No Signs of Growth in Alienation or Support for Extremism" https://www.pewforum.org/2011/08/30/muslim-americans-no-signs-of-growth-in-alienationor-support-for-extremism/

${ }^{4}$ Ibid.

${ }^{5}$ Cato, "Muslim Assimilation Demographics in Education and Income" https://www.cato.org/blog/muslim-assimilation-demographic-education-income-opinionsviolence

${ }^{6}$ Cole, David. "Are we safer?." (2006), p. 3.

https://scholarship.law.georgetown.edu/cgi/viewcontent.cgi?article=1004\&context=facpub 
7 Bridge, "Legal Challenges to Guantanamo Bay Detention Camp" https://bridge.georgetown.edu/research/factsheet-legal-challenges-to-guantanamo-baydetention-camp/

${ }^{8}$ Cole, David, and Jules Lobel. Less safe, less free: Why America is losing the war on terror. New Press, 2007.

9 John L. Esposito and Dalia Mogahed, Who Speaks for Islam? What a Billion

Muslims Really Think, (New York: Gallup Press, 2007) p. 1

10 Media Tenor Global Agenda Index 2016.

http://us.mediatenor.com/images/GAl_2016_web.pdf

${ }^{11}$ Center for American Progress, "The Roots of the Islamophobia Network in America" http://www.americanprogress.org/issues/religion/report/2011/08/26/10165/fear-inc/

${ }^{12}$ CAIR, "UC Berkley Report Reveals Funding, Negative Impact of Islamophobic Groups in America"

https://ca.cair.com/sfba/updates/new-cair-uc-berkeley-report-reveals-fundingnegative-impact-of-islamophobic-groups-in-america/

${ }^{13}$ http://www.prri.org/research/survey-anxiety-nostalgia-and-mistrust-findings-from-the-2015american-values-survey/

${ }^{14}$ ISPU, “American Muslim Poll Findings, 2017" https://www.ispu.org/americanmuslim-poll-2017-key-findings

${ }^{15}$ https://www.pewforum.org/2017/07/26/findings-from-pew-research-centers-2017-survey-of-us-muslims/

${ }^{16}$ Pew, "U.S. Muslims Concerned about Their Place in Society, but Continue to Believe in the American Dream" https://www.pewforum.org/2017/07/26/findings-from-pew-research-centers2017-survey-of-us-muslims/

${ }^{17}$ https://www.pewresearch.org/2007/05/22/muslim-americans-middle-class-and-mostly-mainstream/ 